Cronfa - Swansea University Open Access Repository

This is an author produced version of a paper published in :

Race \& Class

Cronfa URL for this paper:

http://cronfa.swan.ac.uk/Record/cronfa33861

\title{
Paper:
}

Burnett, J. (2017). Racial violence and the Brexit state. Race \& Class, 58(4), 85-97.

http://dx.doi.org/10.1177/0306396816686283

This article is brought to you by Swansea University. Any person downloading material is agreeing to abide by the terms of the repository licence. Authors are personally responsible for adhering to publisher restrictions or conditions. When uploading content they are required to comply with their publisher agreement and the SHERPA RoMEO database to judge whether or not it is copyright safe to add this version of the paper to this repository. http://www.swansea.ac.uk/iss/researchsupport/cronfa-support/ 


\section{Racial violence and the Brexit state}

Whatever else Brexit means or does not mean, it certainly means racism. Born of fortuitous circumstances, lacking programme or policy, the government has had to find its 'mandate' in the twin Brexit themes: that immigration is unravelling of the nation, and anything foreign, except investment, is abhorrent to its ethos - thus giving a fillip to popular racism and elevating institutional racism to fully-fledged state racism.

Of course there were signs of state racism from the time of the first Immigration Act in 1962, but these were counterbalanced by anti-discrimination legislation and community programmes - and for a while the way was opened to a truly multicultural society, the foremost in Europe, and its exemplar. The difference today is that racism and xenophobia have become tied into the state itself, making nativism the state ideology and 'take back control' its political culture.

In the post-referendum period, racial violence and harassment, as this report graphically shows, became widespread and brazen. But in going along with the dominant narrative, the government reduced racial violence, a socially-based issue, to individualised 'hate crime'. And in so siphoning off racism and racial violence to the terrain of law and order, the government conceals its complicity in creating state racism.

The struggle then is on two levels, both at once: against state racism and against 'hate crime'.

\section{A. Sivanandan}

The explosion of racist violence that followed the announcement of the EU referendum result on 24 June 2016 has been well documented. Though the political direction of travel in the UK on issues of immigration, race, religion and refugee policy has largely been disconnected from that violence, the sheer level of racist abuse and attacks could not be ignored. Home Secretary Amber Rudd, launching a hate crime strategy a few days after the referendum, declared that hate crimes were 'utterly unacceptable' and must be 'stamped out'. Former Prime Minister David Cameron described the situation as 'despicable', ${ }^{1}$ whilst the new one, Theresa May, said that hate 'has no place in the UK' ${ }^{2}$ For Metropolitan Police Chief Bernard Hogan-Howe, the 2,300 (plus) racist incidents reported to the police in the thirty-eight days after the referendum, were a 'horrible spike'. 
The Institute of Race Relations' thesis is that the spike in race hatred has had a direct impetus from the divisive approach to race, religion and migration which is now official policy. To put it simply, if a hostile environment is embedded politically, why should we be surprised when it takes root culturally? What do hate crimes tell us about the culture of the country we are living in, and is it possible to trace a relationship between 'hate', media frameworks, government policy and institutional practices? These are the questions we seek to answer in our examination of post-referendum racial violence. ${ }^{4}$

\section{The legitimation of racial violence}

In the aftermath of the EU referendum, incidents of racist abuse began to be shared on social media almost immediately, with several online platforms being set up specifically to collate and document the extent. Long-established advocacy and campaigning organisations also noted sharp increases in the number of incidents being reported to them, as well as requests for support. A few weeks after the referendum, for example, The Monitoring Group brought hundreds of people together in London in order to 'respond, address and move forward' in a 'hostile and racially charged Britain'. ${ }^{5}$ Meanwhile, the Bristol-based Stand Against Racism and Inequality (SARI) revealed that more people were approaching it for advice, and Just West Yorkshire later called for an audit of 'race hate crime arrangements' because of concerns about the response to violence and abuse in the region. ${ }^{6}$ The police, meanwhile, were producing regular statistics on hate crime, and there was an intense media focus on racist violence in the UK, with particularly brutal incidents receiving blanket coverage.

- In the first four days after the referendum, 85 hate crimes were reported to True Vision - a police-funded online reporting mechanism - compared to 57 in the same period four weeks earlier.

- In the seven days after the referendum, the National Police Chiefs' Council (NPCC), which runs the True Vision online reporting mechanism, received 331 allegations of hate crimes, compared with a weekly average of $63 .^{7}$

- In the fortnight after the result, British Transport Police (BTP) received 119 allegations of racist abuse or violence taking place on British railways. ${ }^{8}$

- Between 24 June and 2 July, 599 racist incidents were reported to Scotland Yard: an average of 67 per day, compared to 44 per day prior to the referendum. ${ }^{9}$

- Between 16 June and 30 June, more than 3,000 hate crimes were reported to the police across the UK: a $42 \%$ increase on the same period in $2015 .^{10}$ 
Whilst the majority of the 134 incidents examined were incidents of racist abuse, they also included physical assaults, arson attacks, death threats and stabbings. Several people were hospitalised. Most of these incidents were in England; and whilst the most frequent 'targets' were European migrants (particularly eastern European migrants) and Muslims, these were not the only people targeted. There were incidents against black people. Jewish people were targeted. People were singled out for attack on the basis of speaking a foreign language, or presumptions about their 'right' to be here. Children were amongst those who received abuse, sometimes travelling to or from school.

Fifty-one of the incidents included references either explicitly to the EU referendum and its outcome, or the messages that it conveyed (such as 'taking the country back'). And there has been a distinct intensification of particular forms of racist violence which link to it.

\section{The referendum result was taken by some as affirmation that the country was} not only now 'theirs', but that it was theirs 'again'. In this way, there was a sense of history being corrected and of historical wrongs (immigration, primarily) being righted. One person for example, who racially abused a woman in London, referred to 'this lot' having lost the election, and that it was time for them to 'go back' out of 'our country'. Another person was asked if he was from the EU and then told to 'fuck off back to your country' and to 'get the fuck out of our country'. One person who was assaulted was chased by his attacker first, who also shouted 'go back home you fucking immigrant'.

\section{The referendum was envisaged as a sign that a set of assumed legal and cultural} 'norms' could be reasserted. Thus, for example, in one incident a woman walking with her 9-year-old daughter was approached by a man who racially abused her, ripped off her niqab and reportedly told her 'You're in Britain, live by British rules'. In another, a threat of anti-Muslim violence was accompanied by the message that there is only 'one law' in the UK, and that the victim had to 'abide by it'. An eastern European woman was reduced to tears by a man telling her to 'Just go home. We voted you out. You will have to leave the country soon'. When she threatened to call the police, the man's response was to tell her to call 'whoever you want' as this is 'our country, our law'. What these and other incidents pointed to was the manner in which the referendum fostered a notion that a set of institutional norms, which had been subverted by the presence and management of 'diversity', could now be reestablished. 


\section{The racist violence that was legitimised was underpinned by a racism tied to}

'entitlement'. The racist abuse of one person mistakenly assumed to be a Polish national, who was told 'we only tolerate you lot because of the income you bring in', indicated a form of racism within which people were only accepted in the UK on the basis that they brought skills/capital. In another, a homeless migrant was deliberately picked out and assaulted, in part because he was homeless. Here was a very clear message: outsiders are acceptable only when profitable.

\section{Voting or visibly campaigning for the UK to remain in Europe was taken by} some to be a form of betrayal. In a few isolated cases, people from BAME communities were targeted after the referendum result seemingly because they had actively campaigned prior to it. One locally prominent 'Remain' campaigner found that the windows of his business had been smashed; another activist was accosted and told to 'get out the country'.

5. Anti-migrant and anti-Muslim racism, in particular, intersected in the context of the EU referendum. The EU referendum, of course, did not create racism. Rather, the campaign drew on and fed into existing forms of racism, particularly Islamophobia, whilst underpinning forms of racism of its own. As our sample illustrates, the range of people targeted was broad, and in around two-thirds of the incidents, the victims were Muslims or eastern European migrants. This should not be surprising. For in the context of a referendum which in many ways became a proxy for a debate about who should or should not be in the UK, and if so under what conditions, anti-Muslim racism and anti-migrant racism intersected. In both cases, the targets have been portrayed routinely as societal antibodies. In both cases, they are regarded as undermining and irreversibly transforming the cultural and political basis of the nation. For Muslim communities the debate, over the last few years, about British values in the context of counter radicalisation measures, has led to a situation in which Muslims as a whole are presented as holding values antithetical to Britishness.

6. The 'newness' of post-referendum racism is rooted in and sustained by the structural racism of 'old'. There has been a significant upsurge of interest in racial violence after the referendum, with the implication that a previously 'tolerant' nation has been tipped over some precipice. But this is ahistorical. As we have emphasised elsewhere, the abuse that appeared to characterise much of the post-referendum racism that we have documented - 'go home', 'taking our country back' and so on has historical echoes. The racism that has certainly intensified following the 
referendum is given legitimacy not just by the referendum itself, but by the forms of racism embedded as national policy in the decades leading up to it, for example in debates over immigrant numbers, media scares about scroungers, policies like Prevent which stigmatise whole communities. And in this context, it is indicative that certain messages previously belonging solely to the far Right are now found in dominant policy positions.

\section{The racial violence that has intensified following the referendum result is the}

fallout of policy. In the above context, the racist violence that has followed the referendum is not a just a 'spike', a 'jump' or a 'spate', as the mainstream consensus has it. It is the literal manifestation of the political climate which sustains it. As a report published by three groups set up after the referendum has suggested istreetwatch, Worrying Signs and \#postrefracism - the 645 racist incidents it collated on social media are indicative of the 'increasing normalisation of xenoracist narratives and the manifestation of the "hostile environment principle". ${ }^{11}$ And the Commission for the Elimination of Racial Discrimination (CERD) has warned that UK counterterrorism policy has 'created an atmosphere of suspicion towards members of Muslim communities'. ${ }^{12}$ And this comes on the back of repeated criticisms, including a statement from the independent reviewer of terrorism laws that the Prevent strategy causes 'mistrust'. 13

We would go further. Almost every utterance shouted alongside a specific racist attack, is already a dominant ideological policy position. In other words, much of the racist abuse that has followed the referendum result has had its gestation within policy measures which express the same aim. There is a parallel, of course, between the 'leave' campaign's unofficial slogan of 'taking the country back' and the racist abuse that urges the same. But there is also a parallel between the racist assault of a homeless migrant, who is not deemed to be economically productive, and the public spectacle of the police, immigration authorities and other agencies rounding up homeless migrants and 'removing' them for the same reason. Likewise, there is a parallel between a racist violence that is practically carried out as some perverse form of public duty and state policies which place legal demands on a variety of agencies to racially profile 'service-users', and track down irregular migrants. And there is a parallel, too, between the abuse of Muslim communities on the basis that they need to live by 'British rules', and a policy framework which routinely demands the same and suggests that this is not the case. A review of some of the policy statements that have dominated the UK in the last five years (see below) makes clear how many of these 
retrograde positions, far from emerging during the referendum debate, preceded it. They have for years been part of Britain's political landscape and, as the Prime Minister has made clear, are now going to intensify in the post-referendum context.


and huswe then in the party

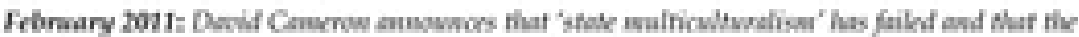

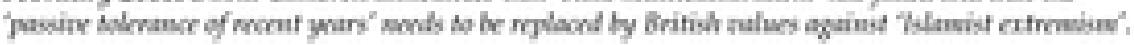

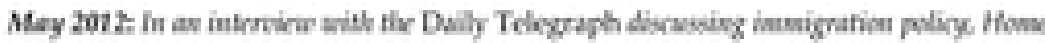

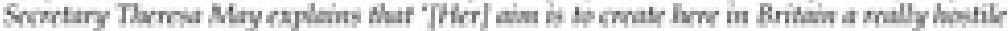



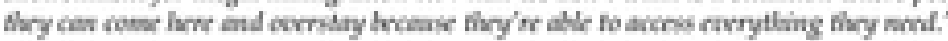

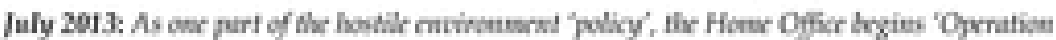

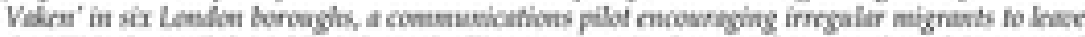

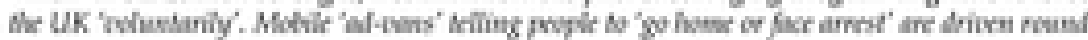



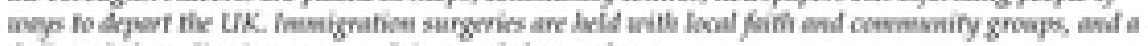

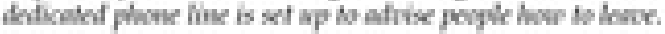

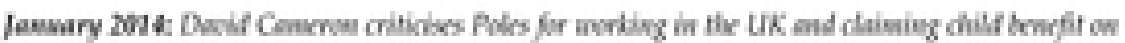

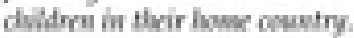

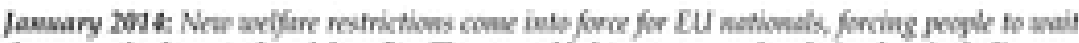

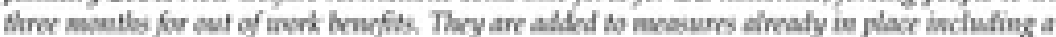

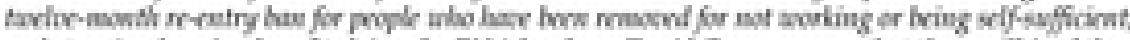

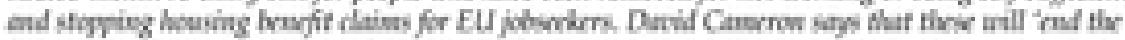

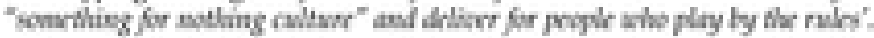

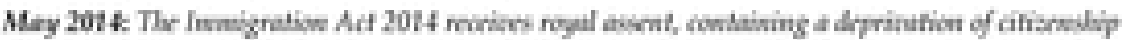

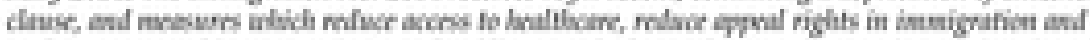


shins dirls.

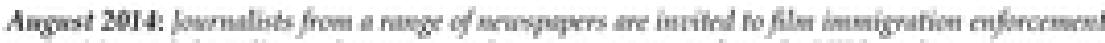

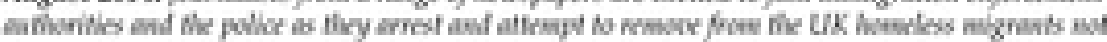

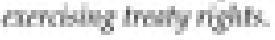

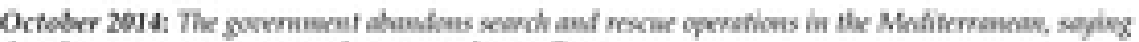

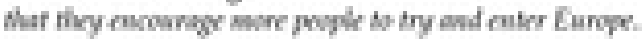

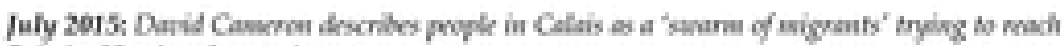

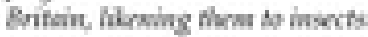

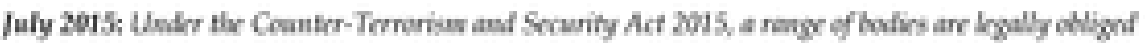

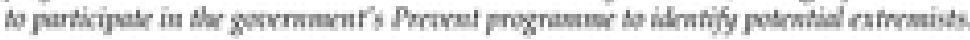

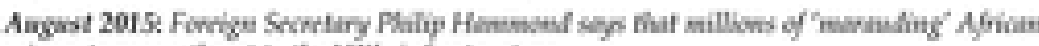

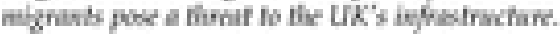

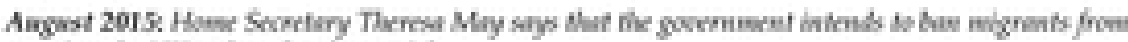

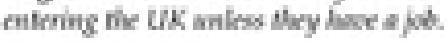



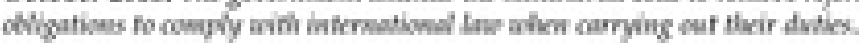

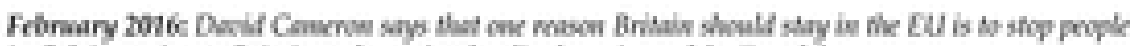

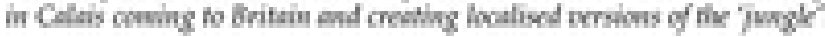

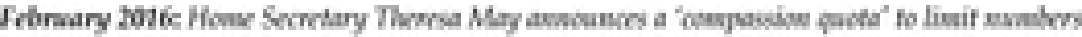

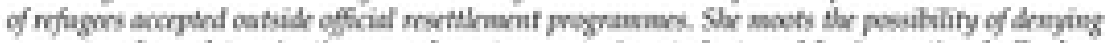

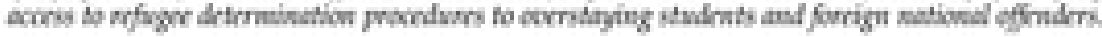

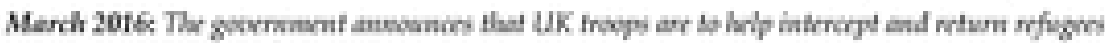
Bying bo mal Forige fow Tarlay.

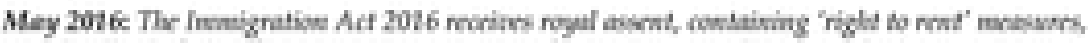

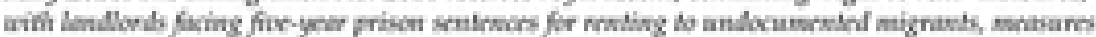



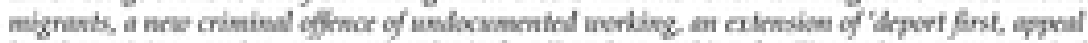

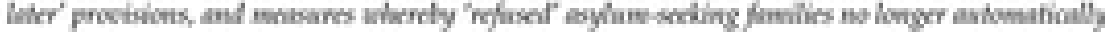



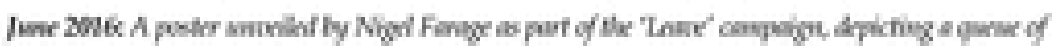

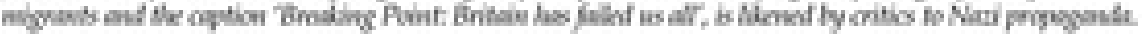

\section{View larger version}




\section{The interpretation of racial violence}

Smug political elites are disconnected from the problems of ordinary people struggling under the impact of market forces. And much post-referendum analysis has correctly interpreted the Leave vote as a protest vote against this, not just against immigration. But, ironically, when it comes to post-referendum hate crimes, the same analysts and media commentators shy away from any political analysis, and show scant awareness of the long history of racist violence in the UK. Liberals from the 'Remain camp', in particular, have clung to the belief that racist hate crimes are simply a by-product of Brexit, whilst Conservatives in the 'Leave camp' argue that racism is down to a minority who have misunderstood the legitimate demand to 'take back control' - a view reinforced by the Daily Mail and the Sun which both supported the Leave campaign. Either way, racism is represented as a failing located within a thuggish minority, to be punished and dealt with solely under the rubric of law and order.

Within each narrative, it was accepted, in the immediate aftermath of the referendum at least, that there had been a surge in violence and that the most important thing was to deal with it quickly in order to preserve social cohesion and the social order. It was the increased level of media reporting in those initial days that framed such an acknowledgement. A closer examination of the stories reported, however, reveals the very narrow lens through which the media looks, which, in turn, reproduces very limited understandings about racism.

According to our data, the numerical upsurge is clear. There were almost seven times more racist incidents reported on by the media in the month after the referendum (134) than in the same month in 2015 (21). A statistic that whilst reflecting an increase in incidents of racist violence, on the one hand, indicates a heightened interest in racial violence, on the other. But what this increased reporting of racial violence also reflects is the way in which the relationships between the media, the criminal justice system and political authorities were shaping notions of how post-referendum racism was to be understood.

Relying on the police for the story

Following the referendum result, the National Police Chiefs' Council (NPCC) requested weekly 'returns' on reported hate from police forces. Eight weeks later, it decided to stop publicising the weekly returns, effectively sending out a signal that the 'surge' or 'spike' 
was now subsiding. ${ }^{14}$ Figure 1 shows the proportion of hate crimes reported to the NPCC in the week before, and the eight weeks after the referendum (when 'returns' were no longer obligatory) compared to the corresponding weeks in 2015. It also presents data from media-reported incidents on our database. And as it suggests, the media reporting of racial violence increased, initially, at a much higher rate before, eventually, falling roughly in line with police statistics.

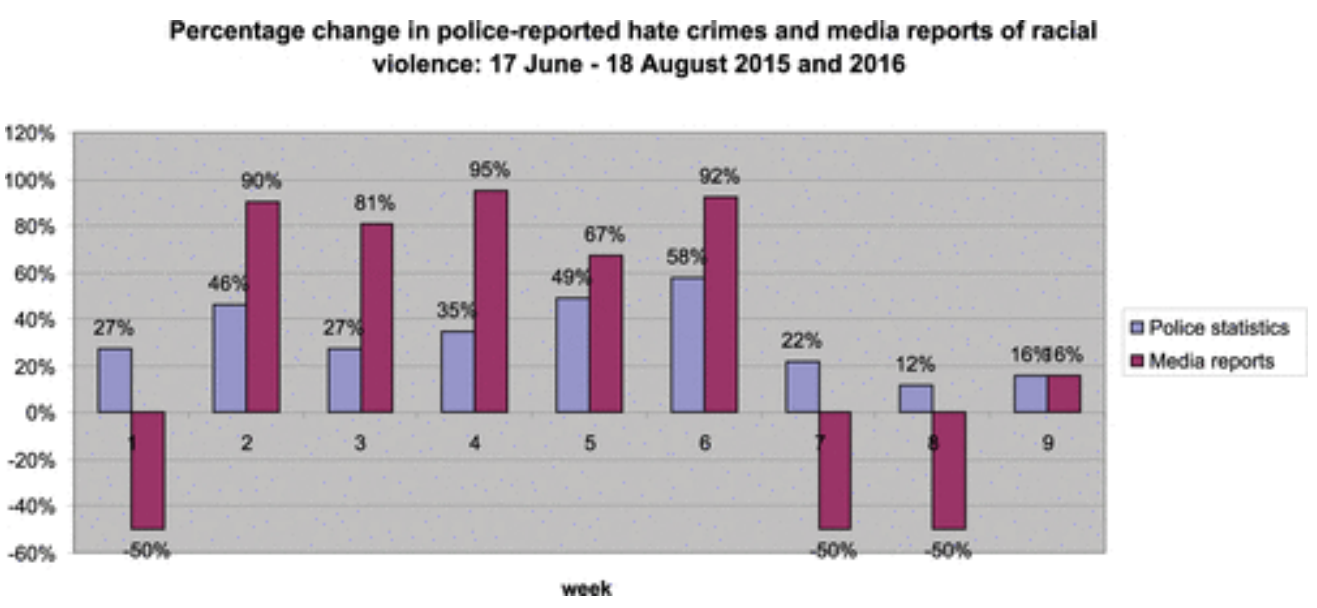

Figure 1. Percentage change in police-reported hate crimes.

Why is this significant? One reason is that it suggests that the media defers to the police when deciding when racial violence is newsworthy. In the month after the referendum, of the 134 incidents that we collated, sixty-one (47 per cent) appeared to originate from the police, either from press releases appealing for information about an incident, or from otherwise police-initiated stories. This does not include a further 16 per cent of stories which appeared to originate from other criminal agencies and representatives. Or, in other words, following the referendum the criminal justice system was a dominant source of information on racist violence and which examples of racist attacks to highlight.

Through the Freedom of Information Act we obtained data on the number of racist incidents recorded by each police force in the month after the referendum. The total number of incidents recorded from the fifteen police forces that reported the highest numbers was 6,516. When compared to the media-reported incidents that we collated, this would indicate that police forces, on average, either released information publicly on, or the media reported on, around 2 per cent of this number. This is consistent with many other forms of interpersonal violence. But given the media's apparent reliance on the police as 'a source', it does provide one indication of the extent to which a level of selectivity exists as to which racist attacks are brought to public attention, and in what 
context. Whilst the media focus on racial violence intensified, the number of incidents brought to public attention to frame this discussion were few. And one implication is that, from our sample at least, information appears to be released on those incidents where policing appears to reside at the centre of the solution to racist violence.

'Balance' and the construction of consensus

The criminal justice system does not just have a role in providing information as to which incidents of racist violence to look at - our sample indicates that the media invariably looks to the police, too, to interpret such violence. According to our data, there is a hierarchy of interpretation which, in practice, means that when the media seeks to give meaning to an incident it turns (respectively) to the police, other criminal justice agencies, political figures, 'community representatives' and only finally to the victims or victims' families.

The journalistic notion of 'balance' and 'objectivity' is central to this. For, according to our data, when stories originated from outside established sources of authority (from the public, for example), it was almost always left to the police, or some other accredited institution, to interpret them. (Conversely, this was less likely when a case originated from the criminal justice system itself, and its portrayal of events did not need to be 'balanced' by another.) Even when victims of racist violence were approached for comment about racist attacks, it was generally only in terms of the emotional impact that an attack had had. That is, they were approached only as 'victims'. What appeared not to be encouraged was for people to draw on their experience and offer any analysis of why it happened, or what should be done. This, in the majority of cases, was the job for the criminal justice system or other spokespeople speaking from an acknowledged position of authority. Thus 'balance' was maintained, consensus was constructed.

There are a number of consequences to this police and elite-led framing of postreferendum racial violence.

- Policy solutions to racial violence are narrowed to its policing. 'The media', of course, is not monolithic. And there have been a number of detailed and enquiring media investigations into racial violence and living under siege. ${ }^{15}$ Further, there have been some intrepid journalists who have questioned policing following the referendum. But in the main, racial violence is understood as threatening the social order. It becomes a matter for crime-reporting, not for social analysis. The police are 
depicted as a 'thin blue line' defending the nation against chaos, and the solution, therefore, resides in more powers and more resources for the criminal justice system. This was reflected, for example, in the uncritical championing of the government's hate crime strategy after the referendum. That the response to racism resides largely in the bolstering of the criminal justice system, a smattering of educational projects and dealing with under-reporting is accepted as commonsense. Racial violence becomes defined narrowly as a law-and-order issue, without even a nod to all the policies and the climate which provide for its gestation.

The government's updated hate crime plans - 'Action against hate' (2016) - has 'five areas for the next steps for Government and community partners to take to tackle hate crime':

- 'Preventing hate crime by dealing with the beliefs and attitudes that can lead to hate crime';

- 'Responding to hate crime in our communities with the aim of reducing the number of hate crime incidents';

- 'Increasing the reporting of hate crime';

- 'Improving support for the victims of hate crime';

- 'Building our understanding of hate crime'.

- The dominant narrative of racist violence following the referendum consequently becomes one of individualised 'hate', divorced from any political context. At best the context is the language of the referendum itself. Racist violence was generally framed simply as part of a 'spike' following the referendum. This in turn portrayed racism as some kind of aberration in an otherwise tolerant country. According to the deputy commissioner of Scotland Yard Craig Mackey, for example, the referendum result had 'unleashed something in people'. ${ }^{16}$ It was a sentiment echoed again and again by political figures and criminal justice representatives, and reproduced in the media. Without in any way downplaying the level of racist abuse and violence following the referendum, its roots have to be sought in the way that a much broader political context (including the policies and practices of successive governments) had been its pump primer. But unable or unwilling to acknowledge this, political figures have articulated racist violence as the domain of isolated 'thugs' or 'yobs'. The implications of this are that racism becomes defined as something rooted in the actions of a few, often already marginalised, communities. In this framework, it is the 
responsibility of benevolent political figures and a neutral political process to intervene.

- The media disassociates itself from the construction of popular racism. The role of the media is almost entirely removed from any discussion about the creation of a climate which can lead to racial violence. Some of the newspapers and media outlets highlighting examples of racist violence after the referendum, and condemning it the loudest, have in fact been part of concerted long-term campaigns against all manner of 'undeserving' asylum seekers, migrants and BAME communities, not to speak of the demonising of 'terrorist' Muslims. Under the guise of having an 'honest debate' about race and immigration, they have regurgitated tropes of migrant threats/invaders, along with notions of a multicultural enemy within.

Tabloids like the Daily Mail and the Sun, which have consistently spoken up for 'the majority' and attacked migrants and Muslims, sometimes with the most scaremongering of front pages, were amongst the first to embrace a law-and-order stance for dealing with the perpetrators of violence and hate. The Daily Mail, for instance, could be accused of double standards, for condemning the 'hate-filled' 'racist thugs' who set fire to a Polish family's property, when it had carried headlines such as 'Migrants: how many more can we take?'. Likewise the Sun, which had carried headlines such as 'we're stuffed', a 'tide of refugees' is 'filling Europe', now condemns the 'horrific abuse' painted on a refugee family's door. Leader writers at the Sun opined, 'we are appalled at reports of racist abuse in the wake of last week's EU vote and utterly condemn attempts to provoke division in our society', concluding that, 'Anyone caught inciting racial hatred must feel the full force of the law'.

\section{Conclusion}

The racial violence following the referendum, as this report shows, took its brief and even its slogans from the broader racist policies, practices and narratives peddled by previous Labour and Conservative-led governments. But these are assiduously ignored when it comes to providing the official explanation of and remedy for racial violence. Racial violence is, on the one hand, abstracted from the conditions that create and sustain it and re-interpreted as a baseless manifestation of immoral individualised hatred, which, in a democratic society, has to be loudly and publicly condemned. On the other hand, the threat to social cohesion that racism risks, is not, in the official narrative, to be met with social solutions, but through policing. That this narrative is continuously reproduced by 
political figures, establishment spokespeople and media outlets is no coincidence. It emerges from the echo-chamber in which they operate.

February 2013: The Daily Express claims that Britain has been 'Tit by a Romanian crimeroave' in an article headed 'How Ronanians terrorise our streets'.

July 2013: The Daily Express announces that 'foreign scroungers' ane to be 'barred from free NHS treatment'.

September 2013: The Sun demands that teachers and nurses ane banned from waring the veil, and that they are banned in banks, airports and some other areas.

October 2013: The Sun suys there are 600,000 'benefit tourists' in the UK.

October 2013: The Sun admits that there is no evidence to support its claim above.

November 2013: The Daily Express editor leads a delegation to Douning Street to deliver a petition, signed by 150,000 readers 'opposed to a flood of Bulgarians and Ronuanians working in Britain'.

December 2013: On International Migrants Day the Sun's front page staperimposes a big red line over a picture of Europe, telling the Prime Minister to 'stop the flood ... OR ELSE'.

June 2015: An article in the Daily Mail clains that the "tidal wure of mignants could be the biggest threat to Europe since the war'.

November 2015: The Daily Mail runs a cartoon on 'Europe's open bonders' which, in its depiction of Muslims, migrants and rats entering Europe, is likened to Nazi-em propunganda."

November 2015: The Sun distorts its oun polling data to produce a front-pange headline saying ' 1 in 5 Brit Muslims' sympatiny for Jihadis'.

November 2015: The Independent Press Standards Organisation (IPSO) finds a Daily Star Sunday headline 'UK mosques fundraising for terror' to be 'significantly misleading'.

December 2015: The Times claims on its front page that 'Musslims are silent on terror' on the basis of low refermals by Muslim communities to the government's Prezent progmanme.

March 2016: The Daily Star claims that Gypsies have 'invuded' a southern coastal tovon, smying it is 'under siege'.

August 2016: The Daily Mail discusses a 'migration ultimatum' which includes kicking out 'dodgy asylum seekers'.

October 2016: Channel 4 presenter Faitma Manji says that it is now 'open season' on Muslims after IPSO clears a former editor of the Sun, who in July wrote an article condenning her employers for allowing her to uxur a nigab whilst neporting on ferrorist munders in Nia.

a Sydney Smith, 'Daily Mail cartoon on refugees recalls Nazi-era propaganda, critics say', imediacthics (22 November 2015), http://www.imediaethics.org/daily-mail-cartoon-on-refugees-recalls-naziera-propaganda-critics-say/

Figure 2. Examples of strident headlines.

If this report augurs anything it is the danger of what a nativist Brexit state will look like. 'Brexit means Brexit' is already being translated for BAME and migrant communities into 'Brexit means racism' - not just on the ground but also in the repressive proposals already emanating from politicians and government departments in October 2016. For example, pregnant women having to hand over proof of immigration status before giving birth in hospitals, a proposed targeted visa system for EU migrants, the Department of Education demanding to know the nationality of school pupils, the proposed calling in of 'debts' of foreigners who have used the NHS. A nation state, which is (in the globalised world of the twenty-first century) defined specifically to divide those who rightfully belong from those 
who do not, will by definition enshrine racism. The discourse we can expect in the run-up to the triggering of Article 50 could be even more pernicious than that of the referendum debate. The referendum may be over but the 'vote' as to what kind of multicultural society we remain is in the making.

\section{References}

Whale Sebastian, 'David Cameron condemns "despicable" racist abuse after referendum result',

1. Politics Home, 27 June 2016, https://www.politicshome.com/news/europe/eu-policyagenda/brexit/news/76638/david-came/

'Hate crime awareness week 2016: Therea May's message', Prime Minister's

2. Office, 8 October 2016, https://www.gov.uk/government/news/hate-crime-awareness-week-2016theresa-mays-message/

3. Weaver Matthew, "Horrible spike" in hate crime linked to Brexit vote, Met police say', Guardian, 28September 2016.

The paper is built around a consideration of 134 racist incidents that were reported in the media in the first month after the referendum: from 24 June to 23 July 2016. It draws on the database

4. developed by the IRR, which uses an online news aggregator which sources stories covered in local and national newspapers, as well as online news services. Where necessary, information has been supplemented through FOI requests.

5. 'Brexit, racism and xenophobia - listen to the event here', The Monitoring Group

(12 July 2016), http://www.tmg-uk.org/brexit-racism-and-xenophobia-listen-to-the-event-here/.

6. View JUST West Yorkshire's press releases here: http://justwestyorkshire.org.uk/.

7. Piggott Mark, 'Hate crimes soar by $400 \%$ in first week after referendum result following Brexit result', International Business Times, 30 June 2016.

8.

'Race hate crime on UK railways soared after Brexit vote, figures show', Guardian, 22 August 2016.

9. Smith Hayden, Hayhurst Clare, 'Three

10. 'Met police deputy chief links Brexit vote to hate crime rise', BBC News (20 July 2016), http://www.bbc.co.uk/news/uk-england-london-36835966.

Komaromi Priska, Post-referendum Racism and Xenophobia: the role of social media activism in 11. challenging the normalisation of xeno-racist narratives (UK, Worrying Signs, iStreetWatch and Post ref racism, 2016). 
Committee on the Elimination of Racial Discrimination, Concluding observations on the twenty12. first to twenty-third periodic reports of United Kingdom of Great Britain and Northern Ireland (Geneva: CERD, 2016).

Anderson David, Supplementary written evidence submitted by David Anderson Q.C.

13. (2016), http://togetheragainstprevent.org/wp-content/uploads/2015/08/Written-evidencesubmitted-by-David-Anderson-Q.C..pdf.

'Tackling hate crime remains a priority', National Police Chiefs'

14. Council, 7 September 2016, http://news.npcc.police.uk/releases/tackling-hate-crime-remains-apriority.

15. Younge Gary, "Eggs thrown, windows smashed, a family attacked in a park": how Brexit impacted east Europeans', Guardian, 31 August 2016. Google Scholar

16. 'Hate crime "still far too high" post-Brexit - police', BBC News, 22 July 2016, http://www.bbc.co.uk/news/uk-36869000. 